AGNIESZKA GOŁDA

Instytut Bibliotekoznawstwa i Informacji Naukowej

Uniwersytet Śląski w Katowicach

e-mail: agnieszka.golda@us.edu.pl

\title{
Z PROBLEMÓW FORM PIŚMIENNICZYCH BIBLIOGRAFII W ŚRODOWISKU CYFROWYM
}

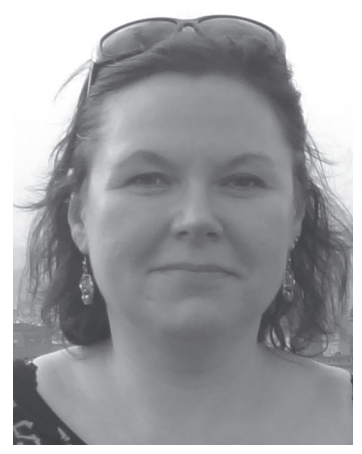

\begin{abstract}
Agnieszka Gołda, dr, pracownik Zakładu Bibliotekoznawstwa w Instytucie Bibliotekoznawstwa i Informacji Naukowej Uniwersytetu Śląskiego w Katowicach. Zainteresowania naukowe: teoria i historia bibliografii, dzieje czasopism religijnych, współczesna prasa bibliologiczna i informatologiczna. Autorka książek: Teoria bibliografii w II Rzeczypospolitej (Katowice 2018), Z zagadnień form bibliografii. Monografia bibliograficzna (Warszawa 2005), Monografia bibliograficzna. Analiza modelowa (Częstochowa 2003), Tygodnik katolicki "Niedziela" 1926-1939 (wspólnie ze Zbigniewem Żmigrodzkim, Częstochowa 2002). Redaktor naczelna kwartalnika „Nowa Biblioteka. Usługi, Technologie Informacyjne i Media".
\end{abstract}

SŁOWA KLUCZOWE: Bibliografia. Formy piśmiennicze bibliografii. Bibliografia „pełna”. Materiały do bibliografii. Zestawienie bibliograficzne. Bibliografia zalecająca. Spis lektur. Bibliografia załącznikowa. Bibliograficzne bazy danych. Środowisko cyfrowe.

ABSTRAKT: Tezy/cel artykułu - W ostatnich latach wiele elementów tradycyjnie pojmowanej bibliografii zmieniło się wraz z zastosowaniem technik komputerowych. Wpłynęły one również na metodykę klasycznych, niegdyś drukowanych spisów bibliograficznych. Celem artykułu jest analiza obecności oraz cech/funkcji/zastosowań wybranych form piśmienniczych bibliografii w środowisku sieciowym. Metody badań - Na podstawie analizy znanych z teorii bibliografii form piśmienniczych bibliografii wyselekcjonowano opraco- 
wania mające postać rejestrów, a więc bibliografie „pełne”, materiały do bibliografii, zestawienia bibliograficzne (tematyczne), bibliografie zalecające, spisy lektur oraz bibliografie załącznikowe. Zastosowano ponadto metodę krytyki źródeł, by ukazać najważniejsze cechy form piśmienniczych bibliografii, oraz metodę porównawczą by skonfrontować spisy w wersjach analogowych i elektronicznych. Wyniki i wnioski - Formy piśmiennicze bibliografii znalazły swoje miejsce w przestrzeni internetowej, ale przynajmniej część z nich znacznie zmieniła swoją postać. Przykładem są bibliografie „pełne” oraz materiały do bibliografii, które funkcjonują jako bibliograficzne bazy danych o wciąż ewoluujących zakresach i zasięgach, zmieniając swoje oblicze zgodnie z oczekiwaniami użytkowników tych narzędzi. Stają się one coraz częściej już nie tyle bazami bibliograficznymi, co bazami dążącymi do udostępniania pełnych tekstów z wieloma funkcjonalnościami, w tym charakterystycznymi dla bibliografii 2.0. Mniej zmian w wersjach cyfrowych form piśmienniczych bibliografii można zaobserwować w zestawieniach bibliograficznych, bibliografiach zalecających i spisach lektur, o ile nie pełnią funkcji komercyjnych (promocyjnych i handlowych), których obecność w sieci ułatwia jednak odnajdywanie informacji wąskospecjalistycznych i sprofilowanych. Z kolei tworzenie bibliografii załącznikowych stało się łatwiejsze dzięki generatorom i menedżerom bibliografii.

\section{WPROWADZENIE}

W klasycznej typologii opracowań bibliograficznych, zaproponowanej po II wojnie światowej, jednym z kryteriów ich podziału jest forma piśmiennicza (dziś powiedzielibyśmy kompozycyjna lub strukturalna, pełniąca określone funkcje, ale niezwiązana z nośnikiem). W 1956 r. Maria Dembowska, rozważając problem form piśmienniczych bibliografii, wyróżniła te o standardowej budowie, a więc spisy, oraz takie, które zostały wyrażone tekstem złożonym z pełnych zdań, a nie opisów bibliograficznych. Do tej drugiej grupy zaliczyła omówienia bibliograficzne, stany badań, monografie bibliograficzne i historie poszczególnych nauk (Dembowska, 1956, s. 79). W latach 60. XX w. autorka ta rozszerzyła zakres stosowania pojęcia forma bibliografii na zestawienia o układzie tabelarycznym (Dembowska, 1963, s. 46-48)1. W kolejnej dekadzie Marta Burbianka zachowała przyjęte wcześniej pojęcie formy piśmienniczej bibliografii, wymieniając: opublikowane spisy (w postaci samoistnych wydawnictw zwartych i ciagłych), omówienia bibliograficzne, stany badań i monografie bibliograficzne (Burbianka, 1972, s. 46-49). Potwierdziła to rozumienie w początkach lat 80 . Aleksandra Mendykowa (1981, s. 24-25), a Irena Socha w 1984 r. podsumowała te ustalenia konstatując, że różnorodność form piśmienniczych bibliografii była wynikiem uwzględniania przez teoretyków, jako kryterium podziału, potrzeb odbiorców bibliografii oraz pełnionych przez te wydawnictwa funkcji (Socha, 1984, s. 25) - z czym

\footnotetext{
${ }^{1}$ Badaczka rozważała pojęcie formy wydawniczej bibliografii oraz przedstawiła inne, poza spisami, formy - jak te w układzie tabelarycznym i o budowie nieschematycznej (omówienia bibliograficzne, stany badań, historie nauk, monografie bibliograficzne).
} 
należy się zgodzić. W 2000 r. Zbigniewowi Żmigrodzkiemu zróżnicowane „formy ujęcia materiału” pozwoliły wyodrębnić już 11 form piśmienniczych, których istnienie należy wiązać z wcześniejszymi osiągnięciami bibliografii oraz rozwojem technologicznym. Badacz wyliczył: bibliografie "pełne”, materiały do bibliografii, zestawienia bibliograficzne (tematyczne), bibliografie zalecające, spisy lektur, bibliografie załącznikowe (nazywane w przeszłości kryptobibliografiami) ${ }^{2}$, omówienia (przeglądy) bibliograficzne, monografie bibliograficzne, a ponadto tzw. nowsze formy bibliografii, jak indeksy słów kluczowych, indeksy cytowań bibliograficznych i „current contents" (Żmigrodzki, 2000, s. 37) ${ }^{3}$.

Podsumowując zaprezentowane rozważania, należy stwierdzić, że wśród form piśmienniczych bibliografii można wydzielić trzy grupy opracowań, w zależności od ich postaci: spisy bibliograficzne (bibliografie „pełne”, materiały do bibliografii, zestawienia tematyczne - wyróżniane z uwagi na kryterium kompletności kwerendy źródłowej; bibliografie zalecające, spisy lektur, bibliografie załącznikowe - których cechą wspólną jest przeznaczenie), opracowania, które nie są rejestrami, a dane bibliograficzne omawiane są w treści książki lub artykułu, względnie cyklu artykułów (omówienia bibliograficzne, monografie bibliograficzne, stany badań, historie nauk) oraz $\mathrm{tzw}$. nowsze formy bibliografii, charakteryzujące się nieco innym rodzajem identyfikacji dokumentów (indeksy słów kluczowych, indeksy cytowań bibliograficznych i "current contents") ${ }^{4}$. Każda z tych form piśmienniczych może być publikowana samoistnie i niesamoistnie wydawniczo (książka, artykuł) lub piśmienniczo (osobna praca, załącznik do tekstu).

Tego typu formy piśmiennicze bibliografii zostały wyodrębnione wśród tradycyjnych opracowań. W ciągu ostatnich lat nastąpiła jednak wyraźna ewolucja nośników prac bibliograficznych. Ewa Andrysiak upatrywała jej w kilku zjawiskach. Ogłaszanie spisów drukiem (samoistnych wydawniczo i piśmienniczo) stało się wobec malejących nakładów nie-

2 Jak zaznaczył Adam Nowak, już w średniowieczu, a dzięki Stefanowi Vrtelowi-Wierczyńskiemu wiadomo, że i w starożytności, można poszukiwać zalążków takich form bibliografii jak bibliografie zalecające, załącznikowe, biobibliografie i autobibliografie (Nowak, 2016, s. 15).

${ }^{3}$ Formy te były przedmiotem zainteresowania teoretyków i metodyków bibliografii z różnym natężeniem. Jak wskazuje analiza zawartości Polskiej Bibliografii Bibliologicznej (1995-), bibliografiom załącznikowym poświęcono 29 opracowań w postaci wydawnictw zwartych i artykułów; swoją literaturę mają również tzw. nowsze formy bibliografii (na przykładzie konkretnych opracowań, jak choćby Science Citation Index, CYTBIN), a ponadto monografie bibliograficzne i bibliografie zalecające.

${ }^{4}$ Indeksy słów kluczowych zaczęto opracowywać w latach 50. ubiegłego stulecia. Na zapis bibliograficzny składały się wyodrębnione w kontekście, lub poza nim, słowa kluczowe (pochodzące z tytułów, adnotacji lub abstraktów) wraz ze skróconymi opisami bibliograficznymi. Porządek alfabetyczny takich zapisów umożliwiał poszukiwania o charakterze rzeczowym. Inną formą bibliografii były bazy łączące z sobą opisy źródeł cytujących i cytowanych - czyli indeksy cytowań bibliograficznych. Do bibliografii prospektywnych można natomiast zaliczyć „current contents”, a więc reprodukowane spisy treści czasopism, które ogłaszano zanim ukazały się pełne wersje periodyków (Żmigrodzki, 2000, s. 40-41). 
rentowne. Nastąpiły również problemy z dystrybucją i kosztami reklamy tych publikacji. Jak stwierdziła autorka: „Bibliografie, które należą do wydawnictw kosztownych, niemogących liczyć również na szybki zbyt, powinny być zatem traktowane w sposób szczególny, a ich dostęp w handlu księgarskim powinien rozkładać się na wiele lat" (Andrysiak, 2007, s. 107). Nie mniej ważnymi przyczynami zmian w bibliografii były potrzeby użytkowników źródeł informacji, oczekujących łatwego, darmowego zazwyczaj dostępu do intuicyjnie obsługiwanych zasobów informacji, osiągalnych $\mathrm{w}$ dowolnych miejscach o każdej porze. Bardziej racjonalnym sposobem przygotowywania i udostępniania opracowań bibliograficznych była więc automatyzacja, w wyniku której bibliografie utrzymywane są w postaci elektronicznych baz danych, mogą być też wydawane w postaci e-booków oraz stanowić kopie drukowanych rejestrów, $\mathrm{np}$. w repozytoriach czy bibliotekach cyfrowych. Komputeryzacja procesów bibliograficznych, której konsekwencją stała się obecność bibliografii w sieci, wpłynęła, co oczywiste, na postrzeganie sposobów istnienia form piśmienniczych bibliografii.

W przestrzeni internetowej dostępne są bibliografie wyróżniane $\mathrm{z}$ uwagi na zakres, jak ogólne, w tym narodowe, oraz specjalne: dziedzin i zagadnień, terytorialne, lokalne, osobowe, zespołów osobowych. Postać baz danych mają również bibliografie wydzielone ze względu na zasięg chronologiczny - retrospektywne, bieżące i prospektywne; oraz na zasięg formalny - np. bibliografie bibliografii, bibliografie wydawnictw ciągłych, zawartości czasopism, dokumentów kartograficznych, ikonograficznych, starych druków, dokumentów dźwiękowych, audiowizualnych, elektronicznych itd. Nieco trudniej zweryfikować w sieci obecność klasycznych form piśmienniczych bibliografii, z wyłączeniem indeksów słów kluczowych czy indeksów cytowań, które już u swojej genezy, były wynikiem zastosowania technik komputerowych (dlatego też nie będą przedmiotem analizy). Jeszcze trudniejsze jest odszukanie w Internecie opracowań o niestandardowej budowie (monografii bibliograficznych, stanów badań, omówień bibliograficznych i historii nauk), które mają postać zdigitalizowaną oraz mogą funkcjonować jako np. artykuły w czasopismach online czy na wortalach naukowych. Cechy pozostałych form piśmienniczych bibliografii - a więc spisów w kilku odmianach, pełniących różnorodne funkcje - staną się przedmiotem wstępnego badania zjawiska. Wskazane zostaną zatem odpowiedniki form piśmienniczych bibliografii w sieci oraz zidentyfikowane cechy odróżniające tego rodzaju rejestry od ich drukowanych ekwiwalentów, które świadczą o zmieniających się zastosowaniach bibliografii (por. rozważania Woźniak-Kasperek, 2010, s. 119-124; Woźniak-Kasperek, 2015, s. 523-524). 


\section{BIBLIOGRAFIE „PEŁNE” I MATERIAŁY DO BIBLIOGRAFII}

Jedną z najwartościowszych form piśmienniczych bibliografii są, według teoretyków bibliografii, bibliografie „pełne”, a więc opracowania przygotowywane na podstawie w miarę kompletnej kwerendy, obejmującej wszystkie potencjalne źródła, zgodnie z przyjętymi w danym rejestrze zasadami zakresu i zasięgów materiałów, z zastosowaniem elementów selekcji formalnej i wartościującej (Żmigrodzki, 2000, s. 37; Czapnik, Gruszka, Tadeusiewicz, red., 2011, s. 33). Dzięki szerokiemu spektrum bibliografowanych publikacji, bibliografie te pełnią istotne funkcje informacyjne i archiwizacyjne. Przykładami ich mogą być opracowania znanego bibliografa i varsavianisty Konrada Zawadzkiego Gazety ulotne polskie i Polski dotyczace XVI-XVIII wieku. Bibliografia (t. 1-3, Wrocław 1977-1990) czy praca zbiorowa Dramat staropolski. Od początków do powstania sceny narodowej. Bibliografia przygotowana przez zespół pod kierunkiem Władysława Korotaja (t. 1-2, Wrocław 1965-1978). Bibliografie „pełne” bywały tworzone przez grupy bibliografów w ciągu wielu lat. Zespół W. Korotaja przeprowadził liczne kwerendy $\mathrm{w}$ bibliotekach polskich i zagranicznych, np. w Kijowie, we Lwowie i w Wilnie, a pośrednio w Pradze i w Dreźnie; przejrzana została zawartość bibliografii ogólnych (jak Estreicherów), drukowanych katalogów bibliotecznych, inwentarzy księgarskich i drukarskich, indeksów ksiąg zakazanych, słowników biograficznych, opracowań z zakresu historii literatury itd. Jedynie zespół bibliografów mógł dokonać tak szczegółowej penetracji źródeł.

Z kolei materiały do bibliografii mają na celu zaspokojenie doraźnych potrzeb informacyjnych - w oczekiwaniu na powstanie bibliografii „pełnych". Dobór publikacji do nich jest ograniczony, np. do pewnych typów dokumentów lub prac wydanych w zamkniętym przedziale czasu (Żmigrodzki, 2000, s. 38). Przykładów opracowań w wersji drukowanej lub e-booków wciąż nie brakuje, np. Jerzego B. Parusela Materiały do bibliografii żubrów pszczyńskich (cz. 1, Katowice, 2015), Stanisława Bąby Materiały do bibliografii frazeologii polskiej. Prace opublikowane w latach 2001-2005 (Poznań, 2008) czy Wacława Sokołowskiego i Haliny Lubicz Materiaty do bibliografii polskiego piśmiennictwa leśnego za lata 1542-1860 (Warszawa, 1995).

Współcześnie obie te formy piśmiennicze są dostępne w środowisku sieciowym. Terminy bibliografia "pełna” oraz materiały do bibliografii przy elektronicznej postaci rejestrów - tracą jednak na swoim pierwotnym znaczeniu, nawet jeśli w opisie baz danych podaje się wyraźnie pewne ograniczenia w doborze materiałów czy stosowanych metodach. Tego rodzaju zasoby mają bowiem postać "otwartą" - bazy o charakterze retrospektywnym lub bieżącym - bez względu na zestaw bibliografowanych zasobów mogą stale zmieniać swój kształt, wzbogacać się nowymi danymi, pochodzącymi z nieprzebadanych wcześniej źródeł. 
Cech bibliografii „pełnych” oraz materiałów do bibliografii można poszukiwać wśród elektronicznych bibliografii narodowych, bibliografii dziedzin i zagadnień, terytorialnych oraz zespołów osobowych, w których dąży się do kompletności rejestracji lub stosuje selekcję wynikającą z potrzeb odbiorców źródeł. Obejmują one opisy publikacji wydanych w określonym czasie, a elektroniczna formuła pozwala nie tylko na przekonwertowanie treści rejestrów wydanych drukiem, ale na ciągłe uzupełnianie kompletności (także materiałem pominiętym w przeszłości z różnych przyczyn) oraz poszerzanie zakresu i zasięgów: chronologicznego, formalnego czy językowego.

Jak wspomniano, jedną z cech bibliografii „pełnych” jest dążenie bibliografów do przeprowadzenia możliwie kompletnych kwerend. Z uwagi na chęć objęcia poszukiwaniami dużej liczby materiałów, bazy bibliograficzne powstają jako zespołowe (kooperatywne) przedsięwzięcia (współkatalogowanie lub współkatalogowanie podzielone ${ }^{5}$, por. Chłopkowska, 2009, s. 232-233; Siwecka, 2015, s. 234-243; Sadowska, 2015, s. 97-98; Sadowska, 2017, s. 7). By ukazać pełny zakres i nieograniczone zasięgi (poza terytorialnymi), centrale bibliograficzne opracowujące bibliografie narodowe coraz częściej współpracują z różnymi instytucjami, jak biblioteki naukowe czy oficyny wydawnicze (np. przez program CIP, dobrze funkcjonujący choćby w Stanach Zjednoczonych). Na Słowacji na zasadzie współkatalogowania istnieją CREPČ - Centrálny register evidencie publikačnej činnosti (Centralny rejestr publikacji naukowych), CREUČ - Centrálny register evidencie umeleckej činnosti (Centralny rejestr działalności artystycznej) oraz CRZP - Centrálny register záverečných a kvalifikačných prác (Centralny rejestr prac dyplomowych) (Kycler, 2015, s. 58-59). Podobne praktyki są charakterystyczne w Polsce czy w Niemczech w zakresie opracowania bibliografii terytorialnych, np. baza Bibliografia Regionalna Dolnego Ślaska przygotowywana jest przez Dolnośląską Bibliotekę Publiczną im. Tadeusza Mikulskiego we Wrocławiu we współpracy z 24 bibliotekami z województwa. Do przykładów kooperacji na poziomie międzynarodowym należy zaliczyć portal bibliograficzny współtworzony w Herder-Institut für historische Ostmitteleuropaforschung w Marburgu, obejmujący bazę historii Europy Środkowej i Wschodniej, w której funkcjonowanie zaangażowane są ośrodki bibliograficzne w Niemczech, w Polsce, w Czechach, na Litwie i na Węgrzech. Prace nad

\footnotetext{
${ }^{5}$ Według Jadwigi Sadowskiej: „należy stwierdzić, że przyszłość należy do otwartych bibliograficzno-abstraktowych baz danych z linkami do pełnych tekstów i innych informacji zewnętrznych (autorzy, instytucje). Przy czym istotne jest, aby bazy były wiarygodne i wartościowe informacyjnie (a to zależy od poziomu naukowego dokumentów oraz od przyjętych zasad selekcji w bibliografii), aktualizowane na bieżąco, z możliwością przeszukiwania według wielu kryteriów formalnych i treściowych, z przyjaznym interfejsem. Natomiast z punktu widzenia efektywności, szybkości opracowania dokumentów, uniknięcia dublowania, bazy dziedzinowe powinny być współtworzone przez grupy ośrodków z danej dyscypliny" (Sadowska, 2017, s. 10).
} 
bibliograficzną bazą danych światowego językoznawstwa slawistycznego iSybislaw nadzoruje z kolei Instytut Slawistyki PAN, a współtworzą ją instytucje językoznawcze z Białorusi, z Chorwacji, z Czech, z Estonii, z Macedonii, z Niemiec, z Rosji, ze Słowacji, z Ukrainy (Sadowska, 2017, s. 7). Bibliografie istniejące na zasadach współpracy międzyinstytucjonalnej zyskują wiele - ogranicza się problemy dublowania prac, a jednocześnie oszczędza się czas na staranniejszą weryfikację źródeł. W wyniku innego rodzaju współpracy powstaje BazTech - baza z zakresu nauk technicznych i ścisłych oraz ochrony środowiska (Narloch, Skrodzka, 2014, s. 5-6). Jako forma piśmiennicza BazTech jest przykładem materiałów do bibliografii, w których rejestruje się zawartość wybranych typów dokumentów - czasopism oraz prac naukowych wydawanych przez reprezentantów porozumienia zawartego przez biblioteki (obecnie 23 jednostki). Twórcy bazy od początku zadbali o uzupełnienie opisów tak istotnymi elementami, jak afiliacje, słowa kluczowe, streszczenia, w miarę możliwości prawnych skany okładek publikacji, a rozszerzona forma współpracy z redakcjami periodyków i wydawcami zaowocowała gotowymi abstraktami i słowami kluczowymi przesyłanymi dyspozytorom bazy. Już od 2007 r. do opisów artykułów dołącza się bibliografie załącznikowe, a od 2008 r. pełne teksty - tym razem na podstawie umów z wydawcami (Narloch, Skrodzka, 2014, s. 6-7). Dzięki temu baza stała się nie tylko bibliograficznym rejestrem, ale naukowym wortalem z pełnymi tekstami artykułów w formacie pdf lub z linkami do stron wydawców dzieł. Na potrzeby takich baz jak $A G R O$, BazHum, BazEkon, Bibliografia Etnografii Polskiej, Etnologii, Antropologii Kulturowej oraz Nauk Pokrewnych i Polska Bibliografia Lekarska digitalizuje się nawet celowo zasoby czasopiśmiennicze. Tego rodzaju praktyki są możliwe dzięki współpracy bibliografów z redakcjami czasopism i oficynami wydawniczymi (Derfert-Wolf, 2016, s. 18-19; Kasprzak, Polarczyk, Gmerek, 2017, s. 2).

Omawiając kolejne cechy charakterystyczne, zwłaszcza dla bibliografii „pełnych”, należy zaznaczyć, że opracowanie kompletnej bibliografii jest w praktyce niemożliwe, ale bibliografie takie jak narodowe wyróżniają się szerokim spektrum bibliografowanych źródeł, bez wprowadzania selekcji (oprócz formalnej). Dąży się w nich do zarejestrowania reprezentatywnego zasobu dokumentującego dokonania publikacyjne narodu, państwa lub w konkretnym języku. Część tego typu baz przygotowywanych jest na podstawie egzemplarzy obowiązkowych, czyli dokumentów ogłoszonych na danym terytorium (national imprint, national output) i z tego choćby względu bibliografie te rzecz jasna kompletnymi nie są. Poza pełnym zakresem, rejestruje się $\mathrm{w}$ tych bazach zarówno dokumenty tradycyjne, jak wydawnictwa zwarte, ciągłe, kartograficzne itd., ale coraz większą wagę przywiązuje się do bibliografowania dokumentów online, ikonograficznych, dźwiękowych, audiowizualnych - uwzględniając szeroki zasięg 
formalny - co jest charakterystyczne także dla bibliografii specjalnych. Opisowi podlegają ponadto eksteriorika, zwłaszcza w krajach o niewielkiej produkcji wydawniczej (wyjątkiem są Niemcy), dzięki którym bibliografie narodowe pełnią funkcję źródła informacji nie tylko podmiotowej, ale i przedmiotowej.

Cechą bibliografii „pełnych” oraz materiałów do bibliografii, którą można odnaleźć w bibliografiach dziedzin i zagadnień ${ }^{6}$, jest z kolei nie tyle dążność do kompletności, ale do odzwierciedlenia obrazu nauki poprzez zastosowanie odpowiedniej selekcji. Bibliografowie na bieżąco weryfikują zawartość tworzonych przez siebie źródeł, by osiągnąć stan uporządkowania terminologicznego i strukturalnego obszarów wiedzy, oraz by przeprowadzać kwerendy zgodne z aktualnym stanem nauki (Jaskowska, 2016, s. 224). Dowodzi to silnego oddziaływania na te bibliografie zmieniających się zakresów dyscyplin naukowych oraz powstawania nowych obszarów wiedzy i umiejętności. W ostatnich latach, z uwagi na wzrastające zapotrzebowanie użytkowników, poszerzono np. zakres bazy PEDAGOG o materiały z dziedziny nauk społecznych (Wierzbicka-Próchniak, Szewczyk-Kłos, 2017, s. 3-4). W bibliografiach dąży się zatem do takiego doboru źródeł, by powstało narzędzie użyteczne, usprawniające proces zdobywania wiedzy: „Wyobraźmy sobie rozgoryczenie użytkownika, który wertuje wielostronicową książkę wymienioną w bibliografii $\mathrm{z}$ adnotacją «m.in. o bibliotece» i ostatecznie znajduje tylko jeden, bardzo ogólny akapit dotyczący danej instytucji. Dlatego w dobie cyfrowych baz danych i digitalizacji skorelowanej z wyszukiwaniem pełnotekstowym, zadaniem bibliografa nie jest uchwycenie wszystkiego, ale wybranie publikacji pod kątem wartości informacyjnej i ułożenie zebranego materiału w klasyfikacyjnej hierarchii" (Szablewski, 2016, s. 209).

Bibliografie dziedzin i zagadnień muszą zatem powstawać na podstawie szerokich kwerend i stosownych selekcji, by spełniać zadania informacyjne. Przykładowo Polska Bibliografia Literacka obejmuje rejestracją znacznie więcej niż wskazuje na to jej tytuł, bo poza literaturą i literaturoznawstwem, w bazie można odnaleźć teksty z zakresu recepcji, teatru, filmu, radia i telewizji, informacje o aktorach i reżyserach - a więc ogólnie

\footnotetext{
${ }^{6}$ Przechodzą one ewolucję, jeśli idzie o strukturę, czego przykładem niech będą zapoczątkowane w 2016 r. zmiany klasyfikacji Polskiej Bibliografii Bibliologicznej, które były wynikiem znacznej specjalizacji informatologii. Poważne zmiany nastąpiły także i w innych działach rejestru, jak Bibliologia czyli obecnie Dział ogólny; natomiast Struktura i dzieje książki oraz Wytwarzanie ksią̇̇i zostały logicznie rozbite na trzy części: Dzieje i wytwarzanie książki, Czasopiśmiennictwo i Inne rodzaje materiałów bibliotecznych. Nastąpiła reorganizacja struktury wewnętrznej Bibliotekarstwa; rozczłonkowaniu poddano dział Użytkowanie książki (Czytelnictwo oraz Inne formy użytkowania materiałów bibliotecznych) (Szablewski, 2016, s. 171-210). Nie do końca jasne są jednak losy tej bazy danych - na stronie WWW widnieje informacja, że ostatnia aktualizacja zasobu miała miejsce 14 marca 2016 r., przy czym objęła publikacje z roku 2010 (por. Franke, Woźniak-Kasperek, 2016, s. 198-201). W 2018 r. ma się jednak ukazać spis za rok 2011, a jednocześnie trwają prace w bazach za lata 2012 i 2013. Rejestrowane są też wycinki prasowe w bazach 2017 i 2018.
} 
pojętej kulturze literackiej. Materiały pochodzą z około 800 czasopism, bibliografuje się książki, prace zbiorowe, wraz z rozpisaniem ich zawartości, rejestruje się informacje z portali internetowych oraz polonika zagraniczne, adnotując znaczną część opisów (np. Jaworska, 2018, s. 248-249). Do Bibliografii Historii Polskiej analizuje się z kolei zawartość około 1000 tytułów czasopism, w tym 300 zagranicznych (Sadowska, 2017, s. 5). W bibliografiach "pełnych” i materiałach do bibliografii rozszerza się również - pod kątem potrzeb środowiska odbiorców - zasięg językowy, by uchwycić ważne wypowiedzi, tworzone nie tylko w języku narodowym, ale i w innych, co jest widoczne w bibliografiach dziedzin i zagadnień, bibliografiach terytorialnych i zespołów osobowych (np. Wierzbicka-Próchniak, Szewczyk-Kłos, 2017, s. 4).

Najwięcej różnic między wersjami drukowanymi a elektronicznymi bibliografii "pełnych" i materiałów do bibliografii wywołanych zostało, podkreślonymi już kilkakrotnie, rosnącymi oczekiwaniami użytkowników oraz uniwersalizacją nauki. Korzystając z drukowanych bibliografii „pełnych” czy materiałów do bibliografii ich użytkownicy musieli zapoznać się z metodyką opracowania, strukturą spisów oraz zaakceptować rodzaje indeksów zaproponowanych przez bibliografów. Dziś, zmieniające się potrzeby informacyjne odbiorców i ich przyzwyczajenia do korzystania z prostych narzędzi wyszukiwawczych, spowodowały, że nastąpiła integracja dotychczas odrębnych narzędzi, np. katalogów bibliotek narodowych, bibliografii narodowych, specjalnych i bibliotek cyfrowych. Tego typu zmianę można zaobserwować w narzędziu oferowanym przez Bibliotekę Narodową w Warszawie, a odpowiada ona w zasadzie kierunkom rozwoju innych bibliografii tego rodzaju․ Przykładowo, katalog Library of Congress w Waszyngtonie pełni jednocześnie rolę bibliografii narodowej i katalogu, natomiast w początkach XXI w. w Niemczech Die Deutsche Nationalbibliographie wkomponowano w katalog Deutsche Nationalbibliothek w Lipsku. Podobnie stało się w Holandii, w Portugalii, w Danii czy na Węgrzech, gdzie rekordy bibliografii narodowych są równoznaczne z rekordami bibliotek narodowych i nie tworzy się odrębnych punktów dostępu do baz (Siwecka, 2015, s. 227-229; więcej o sposobach łączenia bibliografii narodowych z innymi źródłami: Krynicka, 2013, s. 80-82).

Nadal bibliografie narodowe, dziedzin i zagadnień, terytorialne i zespołów osobowych oferują użytkownikom dane w postaci formalnych opisów bibliograficznych i rzeczowych charakterystyk treści, ale wzbogaconych. Mogą nimi być znane $z$ wersji analogowych adnotacje i abstrakty, np. omawiające, wyjaśniające, ustrukturyzowane, zawartościowe

${ }^{7} \mathrm{~W}$ zasadzie procesy bibliografowania i katalogowania egzemplarzy obowiązkowych, będących podstawą przygotowania bibliografii narodowych, są z sobą tożsame. Rekordy bibliografii narodowej stanowią zawartość katalogów narodowych central bibliograficznych (Pasztaleniec-Jarzyńska, 2004, s. 115). 
czy zalecające. Do opisów bibliograficznych, w bazach elektronicznych, dodawane są również wykazy recenzji, notatki o autorach, materiały o charakterze graficznym, jak skany okładek, spisów treści czy ilustracji, a w przypadku baz rejestrujących stare druki - skany tzw. stron kluczowych, obejmujących karty tytułowe, strony z dedykacjami, początkami tekstów zasadniczych, kolofonami, a więc te elementy, które pozwalają zidentyfikować dokumenty (Klenczon, 2009, s. 69; Klenczon, 2016, s. 166; Milewska-Kozłowska, 2013-2014, s. 258). W opisach bibliograficznych można ponadto odnaleźć - co najbardziej pożądane przez użytkowników - adresy URL skierowujące do fragmentów tekstów, np. w księgarniach (by dokonać automatycznie zakupu) lub pełnych wersji w bibliotekach cyfrowych, repozytoriach czy na stronach WWW czasopism elektronicznych. Dzięki temu, jak stwierdził Jarosław Pacek, „Opracowania bibliograficzne pozbawione zostają większości dotychczasowych ograniczeń: terytorialnych, językowych, chronologicznych, czy dotyczących rodzaju opisywanych materiałów. Rekordy w takiej bibliografii wykorzystującej wynalazek hipertekstu i sieci WWW, przestają być statyczne. Spełniają nie tylko funkcję wskazująca, sygnalną, ale zostają ożywione" (Pacek, 2007, s. 244).

Łatwiejsze staje się również nawigowanie między rekordami, np. hasłami autorskimi, nazwami wydawnictw czy też tematami/hasłami rzeczowymi. Zwiększają się możliwości wyszukiwawcze, np. przez zawartość publikacji (wyszukiwanie według spisów treści wydawnictw zbiorowych). Do standardowych indeksów, zawierających informacje o autorze, tytule, tytule czasopisma, miejscu wydania, roku, serii, języku, klasyfikacji, przedmiocie itp. dodawane są bardziej intuicyjne, jak choćby słowa klucze, uwzględniające słownictwo potoczne, a także słowa określające formę źródła, bywa, że w językach obcych. W Polskiej Bibliografii Lekarskiej zastosowanie deskryptorów z tezaurusa Tez-MeSH „umożliwia [...] skorzystanie z opcji wyszukiwawczej explode pozwalającej na wyszukiwanie rozszerzone wzorowane na bazie Medline. Możliwe jest ponadto zawężenie wyników wyszukiwania tylko do tych rekordów PBL, w których wskazany deskryptor został użyty jako hasło główne (również wzorowana na bazie Medline funkcja focus), co skutkuje odrzuceniem z wyników wyszukiwania tych rekordów, w których wybrany termin nie stanowi głównego tematu, a jedynie temat poboczny" (Giermaziak, Ubysz, Głębocki, 2017, s. 5).

Dzięki elektronicznym nośnikom bibliografii „pełnych” i materiałów do bibliografii możliwe są zaawansowane sposoby zarządzania informacją bibliograficzna, jak choćby zapisywanie historii strategii wyszukiwania, użytkownicy mają sposobność korzystania ze schowków (koszyków), „odkładania” interesujących opisów na wirtualne półki, mogą również wysyłać opisy bibliograficzne mailowo. Wzbogacony potencjał tych form piśmienniczych bibliografii sprawia, że dzięki nim można generować ko- 
lejne rodzaje rejestrów, np. zestawień tematycznych, które zapisuje się i drukuje. Pojawiła się ponadto funkcjonalność polegająca na łączeniu opisów bibliograficznych z zasobem bibliotecznym, dzięki której automatycznie wysyła się zamówienia do czytelni, wypożyczalni, a nawet wypożyczalni międzybibliotecznych. $Z$ bibliograficznych baz danych można też pobierać dane rekordów za pomocą kodów QR oraz dokonywać konwersji opisów bibliograficznych z baz do ISO 2709 lub innej formy opisu gotowego do wykorzystania podczas cytowania.

W bibliografiach "pełnych” i materiałach do bibliografii wykorzystywane są ponadto narzędzia znane z mediów społecznościowych: ocenianie publikacji, dodawanie recenzji i wyjaśnień czy plików tekstowych. Tagami oraz komentarzami mogą opatrywać adnotowane opisy bibliograficzne użytkownicy bazy BABIN 2.0 Bibliografia Analityczna Bibliotekoznawstwa i Informacji Naukowej. Bibliografie "pełne” i materiały do bibliografii powstają także z udziałem użytkowników (bibliografia $2.0^{8}$ ), czego przykładem są choćby bibliografie zespołów osobowych poszczególnych uczelni. W Polsce pracownicy akademiccy mają możliwość przesyłania bibliografom informacji o własnych publikacjach, np. poprzez formularze zgłoszeniowe ${ }^{9}$ (np. Jankowska, 2014, s. 51; Woźniak, Ziółkowska, 2015, s. 120). Dane do tego typu źródeł, w których dąży się do kompletności, pozyskiwane są również na podstawie bibliografii narodowych, bibliografii specjalnych, katalogów, corocznych sprawozdań poszczególnych jednostek uczelni oraz dzięki tzw. egzemplarzom obowiązkowym dokumentów ogłaszanych w macierzystych oficynach wydawniczych. Bieżące bibliografie zespołów osobowych (podmiotowe) reprezentują zatem typ bibliografii „pełnych” - są nie tylko źródłem informacji o publikacjach (prace autorskie, współautorskie, redakcyjne, współredakcyjne, tłumaczenia, wywiady, dysertacje, materiały niepublikowane), ale też bazą do przeprowadzania różnorodnych analiz bibliometrycznych (osób, jednostek organizacyjnych, wydziałów i uczelni) ${ }^{10}$, ukazujących ważne z punk-

${ }^{8}$ J. Pacek rozumie przez to zjawisko zarówno pomoc ze strony użytkowników polegającą na dostarczaniu materiałów do opisów, ich tworzenie i otagowywanie (prace te wymagają jednak kontroli); jak i metodę, wykorzystującą takie narzędzia jak: menedżery bibliografii, standardy i języki opisu metadanych (np. FRBR - Functional Requirements for Bibliographic Records; Dublin Core; XML Extensible Markup Language; RDF - Resource Description Framework; OAI-PMH - Open Archives Initiative Protocol for Metadata Harvesting itd.) (Pacek, 2008, s. 38; por. też Pacek, 2010, s. 210-211; Gmiterek, 2016, s. 109-111).

${ }_{9}^{9}$ Odpowiednie przepisy i zarządzenia władz szkół wyższych mobilizują pracowników naukowych do przesyłania w stosownym czasie opisów publikacji, które nie tylko świadczą o dokonaniach naukowych poszczególnych osób, ale są też elementem ich oceny oraz oceny jednostki, którą reprezentują (na podstawie przepisów Ministerstwa Nauki i Szkolnictwa Wyższego).

${ }_{10}$ Moduł bibliometryczny umożliwia ukazanie informacji „o liczbie wszystkich zgłoszonych publikacji ogółem, z podziałem na typy i wyodrębnieniem publikacji polskich i zagranicznych. Umożliwia przez to prześledzenie aktywności piśmienniczej Uczelni za określony przedział czasu pod względem formalno-wydawniczym i zasięgu terytorialnego. Przy zawężeniu - dostarcza bardziej szczegółowych danych dotyczących prac: afiliowanych, wieloośrodkowych, z czasopism indeksowanych w ISI Master Journal List czy czasopism posiadających wartość IF i punktację ministerialną wraz 
tu widzenia ocen współczesnej nauki parametry, jak choćby: czynniki wpływu czyli Impact Factor, wartość indeksu cytowań (w tym H-index czyli indeks Jorge E. Hirscha) (por. Klimko, 2015, s. 16-17), wskaźnik Index Copernicus, punktacja czasopism Ministerstwa Nauki i Szkolnictwa Wyższego oraz numery DOI - Digital Object Identifier ${ }^{11}$.

Trzeba podkreślić, że wskazane nowe funkcjonalności baz bibliograficznych nie mają bezpośredniego związku z formą piśmienniczą bibliografii - są charakterystyczne także dla innych źródeł informacji, za to znalazły oczekiwane przez czytelników spisów nowatorskie zastosowanie. Elektroniczne nośniki bibliografii „pełnych” i materiałów do bibliografii zmieniły zasadniczo zasady organizacji prac nad spisami bibliograficznymi, organizacji zasobów i dostępu do nich oraz wpłynęły na bardziej aktywny udział użytkowników w procesie wzbogacania bibliografii.

\section{ZESTAWIENIA BIBLIOGRAFICZNE}

Zestawienie bibliograficzne (tematyczne, czasami zwane na stronach WWW kwerendą) jako forma piśmiennicza bibliografii obejmuje wąskie tematy (ma znacznie ograniczony zakres), a opisy źródeł często uzupełnia się adnotacjami. Jest to „retrospektywna selekcyjna bibliografia abstraktowa o zakresie ograniczonym do określonego zagadnienia (tematu), sporządzana przez ośrodki informacyjne" (Czapnik, Gruszka, Tadeusiewicz, red., 2011, s. 380). Wśród tradycyjnych spisów tego rodzaju można wydzielić opracowania podstawowe - pierwsze na dany temat, uzupełniające - będące swego rodzaju kontynuacją już kiedyś podjętego problemu oraz związane - czyli pokrewne tematycznie (Żmigrodzki, 2000, s. 38). Zestawienia bibliograficzne były od początku opracowywane dla konkretnych grup odbiorców, którym chciano oszczędzić żmudnych poszukiwań materiałów, często trudno dostępnych. Przygotowywano je dla pracowników nauki i techniki, inżynierów, specjalistów wielu gałęzi przemysłu. Przykładem mogą być „Zestawienia Tematyczne” ogłaszane nieregularnie w 1988 r. przez Instytut Administracji i Zarządzania w Warszawie. Serię „Zestawienie Tematyczne” w latach 1976-1979 publikowała Biblioteka Główna Uniwersytetu Gdańskiego. W jej ramach ukazały się materiały

z ich procentowym udziałem oraz łączną i średnią wartością w stosunku do liczby ogólnej. Przekazuje dane statystyczne na temat tzw. oddziaływania publikacji" (Woźniak, Ziółkowska, 2015, s. 123).

${ }^{11}$ Jednocześnie zasoby tych baz zasilają Polska Bibliografię Naukowa, której celem jest zebranie rozproszonego dorobku publikacyjnego naukowców, jego agregowanie i udostępnianie (w module repozytoryjnym). Zastosowanie oprogramowania OMEGA-PSIR, rozwijanego dzięki zadaniu badawczemu SYNAT (System Nauki i Techniki), umożliwia wykorzystanie zgromadzonych danych w postaci repozytoriów, automatyczne tworzenie raportów oraz prezentowanie w formie graficznej sylwetek naukowców (widoczne są nie tylko publikacje poszczególnych osób, ale też informacje o projektach, patentach, aktywności zawodowej, podjętej współpracy, cytowaniach, promotorstwach itp.) (Dramińska, Kasprzyk-Machata, 2016, s. 200-202). 
dotyczące np. transportu morskiego. W latach 1977-1986 Instytut Organizacji Zarządzania i Doskonalenia Kadr w Warszawie wydawał natomiast "ZT”, będące kontynuacją „,Tematycznych Zestawień Dokumentacyjnych" z lat 1972-1976. Obecnie znaczenie tego typu zestawień, publikowanych na stronach WWW, jest nie do przecenienia w sytuacji rozproszenia dużej liczby informacji w wielu bazach, wobec konieczności przetwarzania i selekcjonowania danych, wyłaniania źródeł ważnych i wartościowych dla wąskich tematów oraz ich odpowiedniego porządkowania.

Najważniejszą rolę w przygotowywaniu tej formy piśmienniczej bibliografii odgrywają biblioteki specjalistyczne. W Bibliotece Centralnego Instytutu Ochrony Pracy - Państwowego Instytutu Badawczego przygotowuje się dostępne online „Bibliograficzne Zeszyty Tematyczne” (za lata 2007-2017), obejmujące w postaci roczników problemy bezpieczeństwa pracy - w podziale na typy dokumentów, z szeregowaniem chronologicznym, ale bez abstraktów. Dotychczas ukazały się zeszyty o tytułach: $\mathrm{Za-}$ wodowe zagrożenia biologiczne; Ryzyko zawodowe. Zagadnienia ogólne; Ryzyko zawodowe. Wybrane stanowiska pracy; Bezpieczeństwo eksploatacji maszyn. Zagadnienia wybrane; Ryzyko zawodowe. Zagadnienia ogólne. Wybrane stanowiska; Wypadki przy pracy; Psychiczne obciażenie praca. Stres i wypalenie zawodowe; Ryzyko zawodowe - aktualizacja (dwukrotnie, drugie - jako zestawienie uzupełniające); Problemy zawodowe osób starszych 50+ oraz BHP w budownictwie. Oddzielnie opracowano również Zestawienie bibliografii dot. zagadnień bezpieczeństwa pracy w budownictwie (OSH in construction sector), wybór ze źródeł międzynarodowych.

Z kolei na stronie WWW Instytutu Badawczego Leśnictwa można skorzystać z bazy Nowości Piśmiennictwa Leśnego, w postaci biuletynu, w którym rekordy opatrzono deskryptorami i symbolami klasyfikacji i podzielono na kategorie tematyczne Leśnej Klasyfikacji Oxfordzkiej (hiperlinki): Lasy, leśnictwo i użytkowanie produktów leśnych - zagadnienia ogólne (ogólne opisy lasów i leśnictwa poszczególnych rejonów); Czynniki środowiska. Biologia. Gospodarka towiecka i rybna; Hodowla lasu i uprawa lasu; Nauka o pracy (badanie pracy). Pozyskiwanie drewna: prace zrębowe i transport. Inżynieria leśna; Szkody w lesie. Ochrona lasu; Pomiar lasu, przyrost, rozwój i struktura drzewostanów, inwentaryzacja i kartografia; Urządzanie lasu. Ekonomika gospodarstwa leśnego jako przedsiębiorstwa. Administracja i organizacja gospodarstwa leśnego; Zbyt produktów leśnych. Ekonomika transportu leśnego i przemystu drzewnego (włącznie z użytkami ubocznymi, dla których należy stosować w razie potrzeby odpowiednie odsyłacze do poszczególnych produktów); Produkty leśne i użytkowanie; Lasy i leśnictwo w gospodarce narodowej. Użytkownicy tego systemu mogą nie tylko przeglądać rekordy, ale też wysłać mailowo zamówienie na kserokopię konkretnego materiału.

Inną formą funkcjonowania zestawień bibliograficznych w przestrzeni informacyjnej jest zlecanie tworzenia tego typu instytucjom dysponują- 
cym dostępem do dużych baz danych. Taką usługę oferuje Główna Biblioteka Lekarska, w której opracowywana jest Polska Bibliografia Lekarska, stanowiąca narzędzie umożliwiające wykonywanie odpłatnych zestawień tematycznych na zamówienie złożone korespondencyjnie, osobiście lub poprzez formularz elektroniczny (Partyka, Urbańska, 2016, s. 134-135).

W tej formie piśmienniczej bibliografii zmiana nośnika - z drukowanego na elektroniczny - nie wywołała większych zmian, jak to miało miejsce w przypadku bibliografii "pełnych” i materiałów do bibliografii. Nadal służą one wąskim grupom odbiorców, stąd np. dostępność na stronach WWW bibliotek instytutów badawczych, a składają się z wyselekcjonowanych przez fachowe służby opisów, obejmujących specjalistyczne tematy. Część tego typu bibliografii ma postać baz danych, a część - jedynie rejestrów w plikach pdf.

\section{BIBLIOGRAFIE ZALECAJĄCE I SPISY LEKTUR}

Inną formą piśmienniczą spisów bibliograficznych są te o charakterze zalecającym, odpowiadające na zapotrzebowanie społeczne, a przeznaczone dla bardzo zróżnicowanych, szerokich grup odbiorców, służące rozwojowi zainteresowań, ale nie badań naukowych (Sawoniak, 1963, s. 49). Od XIX w. powstawały bibliografie wyborowe, oparte na krytycznym doborze materiałów, uznanych przez autorów rejestrów za szczególnie wartościowe i godne polecenia. J. Sadowska przypomniała, że ten typ bibliografii zwany był wówczas „,bibliografią społeczną”, „,bibliografią oświatową", "bibliografią krytyczną" czy "katalogiem rozumowanym”. Publikowano go w postaci wydawnictw zwartych; bibliografie były też zamieszczane na łamach czasopism naukowych, społeczno-kulturalnych, dla sprofilowanych grup odbiorców, a tworzyli je pedagodzy, działacze oświatowi, duchowni, rzadziej - bibliotekarze. Pomagały w wyborze literatury dzieciom i młodzieży, inteligencji, przedstawicielom ludu czy samoukom (Schabowicz, 2011, s. 101-102; Sadowska, 2016, s. 179-180).

Badaczka bibliografii zalecających, J. Sadowska, w odróżnieniu od Krystyny Ramlau-Klekowskiej i Wandy Rogozińskiej, nie nazywa tych pierwszych bibliografii pomagających sterować lekturą bibliografiami zalecającymi. Bibliografie zalecające wywiodła od radzieckich wzorców z lat 40 . XX w. Powiązała je z poradnikami bibliograficznymi, nazywając specjalnym rodzajem bibliografii wyborowych, w których „,kryterium doboru stanowi wartość publikacji z punktu widzenia osiągnięcia założonych celów (ideowych, światopoglądowych, politycznych, społecznych, wychowawczych) wobec określonych grup odbiorców" (Sadowska, 2016, s. 180).

Bibliografie wyborowe czy zalecające zawsze charakteryzowały się selekcyjnością oraz wyspecjalizowanym sposobem doboru materiałów, po 
uwzględnieniu stopnia trudności opisów zebranych pod kątem grup, do których spisy były adresowane ${ }^{12}$. W tego typu rejestrach uwzględnia się publikacje popularnonaukowe, a jeśli już naukowe, to takie, „,które z naukowym ujęciem łączą walory dostępności dla szerszego ogółu (głównie z dziedziny humanistyki)" (Sawoniak, 1963, s. 61). W wykazach na uwagę zasługiwały adnotacje (najczęściej zalecające) oraz aktualna problematyka (Socha, 1984, s. 27; Żmigrodzki, 2000, s. 38-39). W przeszłości przyjmowały one postać planów czytania, poradników dla samouków, poradników tematycznych, katalogów wzorcowych, adnotowanych spisów książek, kart adnotowanych, katalogów księgarskich i wydawniczych oraz ulotek bibliograficznych (także w postaci zakładek do książek) (Schabowicz, 2011, s. 102-103; Sadowska, 2016, s. 184-185).

W ogłaszaniu zestawień mających cechy zalecające przodują biblioteki, które pełnią funkcje dydaktyczne, w tym biblioteki publiczne i pedagogiczne. Na stronach WWW, np. Dolnośląskiej Biblioteki Publicznej im. Tadeusza Mikulskiego we Wrocławiu, można odnaleźć tematy spisów, najczęściej uporządkowanych abecadłowo. Biblioteka udostępnia w formacie doc kilkadziesiąt bibliografii przydatnych uczniom i studentom, a obejmujących szerokie spektrum tematów - od uniwersalnych (np. Detergenty, Motyw gry w karty w literaturze, Reformacja, Rola i udziat sit zbrojnych $R P$ w misji stabilizacyjnej w Iraku) po lokalne (np. Dolnoślaska Izba Lekarska, Kopalnie-zabytki na Dolnym Ślasku). Te bibliografie, wskazane na różnych etapach edukacji, przyniosły opisy skrócone, rzadko adnotowane. Kartotekę zagadnieniową w postaci bazy danych (Bibliografia M21) udostępnia na swojej stronie Pedagogiczna Biblioteka Wojewódzka im. Józefa Lompy w Katowicach. Źródło to obejmuje zagadnienia pedagogiczne, psychologiczne, socjologiczne, literaturoznawcze, bibliotekoznawcze i regionalne. W plikach pdf zestawienia o charakterze lokalnym oraz pedagogicznym ogłasza również Pedagogiczna Biblioteka Wojewódzka im. KEN w Warszawie (dla odmiany w układzie chronologicznym). Ponad 900 bibliografii wyborowych można odnaleźć na stronie Biblioteki Pedagogicznej w Piotrkowie Trybunalskim. Obejmują one przede wszystkim problematykę etyczna, dydaktyczna, wychowawcza, szkolna, rodzinną i społeczna, aż do zagadnień literaturoznawczych. Zestawienia te powstały w oparciu o znaczną selekcję, a opisy uporządkowano według kryteriów formalnych (typy dokumentów, abecadłowo).

12 Inaczej rozumiano funkcje tej formy rejestrów w okresie PRL, kiedy to bibliografie zalecające miały opierać się na doborze materiałów zgodnie z kryteriami ideologicznymi, by służyć kształtowaniu społeczeństwa marksistowskiego, ukazywać tematy „aktualne i społecznie ważne”. Opracowania te propagowały "światopogląd materialistyczny” i służyły indoktrynacji. J. Sadowska wyróżniła w procesie rozwoju tej formy piśmienniczej bibliografii kilka faz: 1946-1956 - bibliografie miały wyraźny charakter propagandowy i polityczny, popularyzowały piśmiennictwo jedynie z punktu widzenia ideologicznego; 1957-1990 - złagodzono wydźwięk ideologiczny poradników bibliograficznych; po 1990 r. - rola tych bibliografii zmalała (Sadowska, 2010, s. 260-265; Sadowska, 2016, s. 180-184, 192-193). 
Do bibliografii o charakterze zalecającym zalicza się też katalogi wydawnicze, księgarskie i antykwaryczne, których głównym celem jest współcześnie zachęta do nabycia materiałów. Wydawnictwa, duże księgarnie oraz antykwariaty dysponują własnymi stronami WWW, na których umieszczają opisy dostępnego repertuaru z podziałem na tematykę, typy dokumentów lub kategorie odbiorców. Jest to świadoma forma promocji działań instytucji, które oferują dostęp do informacji o najnowszych publikacjach (oficyny wydawnicze i księgarskie) lub rzadszych i trudniej dostępnych w handlu (antykwariaty). Funkcja zalecająca tego typu źródeł jest w zasadzie ograniczona do celów marketingowych i handlowych. Opisy - z adnotacjami zalecającymi i tagami - opatrzone są bogatym materiałem graficznym. Użytkownicy tych serwisów mogą dodawać oceny publikacji, opisy, komentarze (np. na forach), recenzje, słowa kluczowe. Możliwe jest pobieranie fragmentów publikacji, wysłuchanie ich, obejrzenie, polecenie znajomym mailowo czy przez portale społecznościowe, przechowywanie w schowkach, zamawianie po wybraniu formy (tradycyjnej lub w formatach plików, np. mobi, epub). Dzięki hipertekstowi swobodnie przechodzi się między opisami innych publikacji tego samego autora, wydawcy, o podobnej tematyce - temu również służy system podpowiedzi tekstów pokrewnych w danej kategorii.

Pewne funkcje bibliografii wyborowych czy zalecających pełnią ponadto przeglądy nowości wydawniczych ogłaszane w czasopismach elektronicznych, profile wydawnictw, księgarń, antykwariatów, autorów publikacji, czasopism recenzyjnych (np. „Nowych Książek”) na portalach społecznościowych, a także wortale literackie i czytelnicze, współtworzone przez społeczności czytelników, np. lubimyczytać.pl, opetaniczytaniem.pl, biblioNETka.pl itp.

Formą piśmienniczą bibliografii, zbieżną nieco w funkcjach z bibliografiami wyborowymi czy zalecającymi, są spisy lektur (spisy książek zaleconych; Czapnik, Gruszka, Tadeusiewicz, red., 2011, s. 313). Rejestry te były w przeszłości wykorzystywane przez uczestników różnych poziomów nauczania i dokształcania. Celem spisów było informowanie uczniów, studentów, kursantów w najprostszy sposób (pierwszy stopień szczegółowości opisu) o najważniejszych lekturach - obowiązkowych lub uzupełniających, czasami w podziale na typy dokumentów (np. Spis lektur filologii polskiej, teatrologii, filmoznawstwa, bibliotekoznawstwa i informacji naukowej. Kraków 1995) (Żmigrodzki, 2000, s. 39). Obecnie tę formę piśmienniczą bibliografii można odnaleźć w przestrzeni internetowej w postaci wykazów podręczników dopuszczonych do kształcenia ogólnego i zawodowego na stronach WWW np. Ministerstwa Edukacji Narodowej (w plikach xls, php). W podstawach programowych ogłaszanych przez Ministerstwo Edukacji Narodowej widoczne są z kolei wykazy lektur - obowiązkowych i uzupełniających. Ich zestawy dostępne są ponadto na stronach WWW 
związanych z edukacją (np. CoPrzeczytac.pl) oraz szkół (np. I Liceum Ogólnokształcącego im. Stanisława Staszica w Chrzanowie) - w podziałach według poziomu kształcenia i klas. Studenci różnych poziomów studiów mogą z kolei odnaleźć spisy lektur w sylabusach poszczególnych modułów (czyli treści realizowanych na zajęciach). Struktura modułów nie pozwala jednak, by studenci otrzymali obszerny wykaz literatury - są to raczej wybrane pozycje, kanoniczne, pomocne jedynie do przygotowania na bieżące zajęcia, rzadko wykraczające poza program modułu.

Różnorodność postaci tych form piśmienniczych bibliografii jest znaczna - przyjęły one kształt baz danych i wortali, z dużą liczbą narzędzi społecznościowych - ale wówczas, gdy pełnią funkcje komercyjne. Jeśli z kolei ich zadaniem jest informowanie i zalecanie wyselekcjonowanej literatury (funkcje pozahandlowe), to rejestry są uboższe w nowoczesne funkcjonalności. Pozostały w zasadzie tym samym wykazem zalecającym co drukowany, tyle że ogłoszono go w sieci, a przez to jest łatwiej i powszechniej dostępny.

\section{BIBLIOGRAFIE ZAŁĄCZNIKOWE}

Najczęściej spotykaną formą piśmienniczą bibliografii są bibliografie załącznikowe (zwane też np. literatura, literaturą przedmiotu, piśmiennictwem, spisem literatury, wykazem literatury, wykazem piśmiennictwa, wykazem źródeł, wykazem źródeł i literatury, źródłami itp., por. np. Sowińska, 2013, s. 32), bez których trudno sobie wyobrazić istnienie publikacji naukowych, popularnonaukowych czy dydaktycznych (Żmigrodzki, 2000, s. 39). Bibliografie załącznikowe obejmują wykazy cytowanego i wykorzystanego piśmiennictwa, takiego, które było inspiracją do napisania tekstu, parafrazowanego, związanego lub stanowiącego uzupełnienie treści. W wielu dziedzinach wiedzy bibliografie załącznikowe, złożone na końcu rozdziału, po artykule lub na końcu publikacji, pełnią równocześnie funkcje przypisów bibliograficznych - co znacznie ułatwia korzystanie z kompletnych opisów, mogących stanowić źródło dalszych poszukiwań.

Tworzenie tej formy piśmienniczej, charakterystycznej dla każdego typu wypowiedzi naukowej, popularnonaukowej czy edukacyjnej, czy to drukowanej czy cyfrowej, ułatwiają specjalne narzędzia dostępne w sieci. Gotowe opisy bibliograficzne można bowiem pobierać z bibliotek cyfrowych, baz danych i repozytoriów. Służą do tego generatory bibliografii i cytowań oraz menedżery bibliografii - programy komercyjne lub darmowe, łatwe w użytkowaniu. Bez konieczności instalowania dodatkowego oprogramowania, dzięki pośrednictwu serwisów społecznościowych, można pobierać dane bibliograficzne dzięki serwisom CiteULike i BibSo- 
nomy, w którym możliwe jest tworzenie opisów w standardach BibTex, HTML, EndNote, MS Office XML w stylach APA, Chicago i Harvard. Serwis ten pozwala na eksportowanie i importowanie informacji bibliograficznych oraz generowanie bibliografii załącznikowych z danych zgromadzonych przez użytkowników w serwisie (Gmiterek, 2016, s. 125-126).

Pewną popularność zdobywają obecnie wspomniane generatory bibliografii i cytowań, jak EasyBib, Cite This For Me, Citation Machine, Harvard Generator (Gmiterek, 2016, s. 127-128; Tafiłowski, 2016, s. 62), ułatwiające tworzenie opisów bibliograficznych różnych typów dokumentów tradycyjnych i dostępnych sieciowo, z wyłączeniem funkcji zarządzania tymi opisami czy dzielenia się nimi między użytkownikami. Bardziej zaawansowanym narzędziem wykorzystywanym do zarządzania zbiorami opisów są menedżery bibliografii, umożliwiające przygotowanie spisów wykorzystanej literatury według różnych stylów bibliograficznych i pobieranie danych do opisów z sieci. Przykładem są darmowe menedżery, jak Zotero i JabRef, czy też odpłatne, w tym RefWorks i Mendeley (np. Pacek, 2008, s. 40-41; Stępień, 2013/2014, s. 187-192). Tego typu programy wspomagają proces generowania opisów (przejmowanie ich np. z baz pełnotekstowych, serwisów internetowych, katalogów OPAC, blogów, podcastów, prezentacji czy kanałów RSS), tworzenia odpowiedniego formatu danych, ich sortowanie i przekazywanie. Dane bibliograficzne można przechowywać np. w chmurze i w dowolny sposób edytować (Gmiterek, 2016, s. 126-128). Menedżery bibliografii mogą wspomagać pracę naukowców, jak i nieco mniej wprawnych w opracowaniu tego typu aparatu naukowego studentów. Niektóre z programów, jak Mendeley, umożliwiają ponadto współuczestniczenie pracowników naukowych w sieci, dzielenie się opisami własnych publikacji oraz polecanie lektury innych źródeł.

\section{ZAKOŃCZENIE}

Znane z tradycyjnych typologii opracowań bibliograficznych formy piśmiennicze bibliografii znalazły swoje miejsce w przestrzeni sieciowej. Najbardziej charakterystyczną ich grupę stanowią bezsprzecznie bibliografie „pełne” oraz materiały do bibliografii, które przybrały postać bibliograficznych baz danych - zmieniających sukcesywnie swoje oblicze, zwiększające zakres oraz zasięgi, zgodnie z potrzebami odbiorców. Bazy te stanowią podstawowe źródła sprawdzonej i wyselekcjonowanej informacji, stają się bazami bibliograficzno-abstraktowymi lub bibliograficzno-pełnotekstowymi, gdyż "Jednocześnie opis bibliograficzny jest połączony siecią linków z informacjami zewnętrznymi w stosunku do niego, znajdującymi się $\mathrm{w}$ innych serwisach. Tym najważniejszym $\mathrm{z}$ punktu widzenia użytkowników połączeniem jest adres do pełnego tekstu. Tego 
dziś oczekują użytkownicy, nie zadowalając się już ani samym opisem bibliograficznym, ani nawet abstraktem" (Sadowska, 2017, s. 9). Przyszłość bibliograficznych baz danych, o formie bibliografii "pełnych" i materiałów do bibliografii, wiąże się zatem z powiązaniem danych formalnych i rzeczowych dokumentów $\mathrm{z}$ ich pełnotekstową reprezentacją co następuje poprzez włączanie tych form bibliografii w projekty bibliotek cyfrowych, repozytoriów, klastrów informacyjnych, portali regionalnych itp.

Formy piśmiennicze bibliografii w swojej wersji drukowanej pełniły niewątpliwie ważne funkcje informacyjne, dokumentacyjne, edukacyjne i promocyjne wobec krajów, narodów, osób czy dziedzin wiedzy. Jako narzędzia "statyczne" dawały jednak ograniczone możliwości wyszukiwawcze, dostępność ich była ograniczona również nakładami oraz miejscami przechowywania. Drukowana forma, zwłaszcza bibliografii „pełnych" i materiałów do bibliografii, w pewien sposób zawężała możliwości ich użytkowania. Obecnie na ich podstawie można prowadzić badania bibliometryczne, budować rankingi jednostek czy też osób, tworzyć samodzielnie nowe zestawienia publikacji, np. tematu, dyscypliny, regionu, osoby, uczelni, jej wydziałów, mniejszych jednostek (Jankowska, 2014, s. 53-54; Woźniak-Kasperek, 2015, s. 519). Formy piśmiennicze bibliografii przeniesione do środowiska wirtualnego, zyskały także inny obraz - jako digital born - dają możliwość wizualizacji danych. Mają jednak konkurencję, jak to określiła J. Sadowska, w postaci Google Scholar, serwisów dziedzinowych, czasopism online, repozytoriów i bibliotek cyfrowych, katalogów OPAC różnego typu. Te źródła mają jednak swoje mankamenty, wynikające $z$ ich charakteru, podczas gdy bibliograficzne bazy danych, zwłaszcza w postaci bibliografii „pełnych”, pozostają źródłem obiektywnym, z zachowaniem zasad naukowego opracowania, o czym świadczą dobrze sporządzone opisy, selekcja i dołączone informacje uzupełniające (Sadowska, 2017, s. 8).

Elektroniczny nośnik form piśmienniczych bibliografii jest z pewnością dla użytkowników łatwiejszym narzędziem do wyszukiwania danych, dającym lepsze rezultaty kwerend, co dzieje się dzięki często intuicyjnym interfejsom czy licznym powiązaniom/relacjom między rekordami, które zwiększają nie tylko możliwości wyszukiwawcze, ale i badawcze, związane $\mathrm{z}$ analizami treści publikacji osoby, recepcji twórczości czy wydarzeń, wielkości produkcji itp. Obecność w opisach bibliograficznych wzbogaconych informacji pozwala ponadto użytkownikom na wieloaspektowe wyszukiwanie, zaawansowani odbiorcy oraz ci, którzy poszukują narzędzi własnego rozwoju, edukacji czy pracy, mogą natomiast uzyskać odpowiedzi na temat wąskospecjalistycznych zagadnień, zebranych w jednym miejscu, odpowiednio dobranych, ustrukturyzowanych, bo przygotowanych przez wyspecjalizowane służby informacyjne. 


\section{BIBLIOGRAFIA}

Andrysiak, Ewa (2007). Wydawnictwa bibliograficzne jako forma ochrony dorobku piśmienniczego. W: Ksią̇ka ponad podziałami. Pod red. Antoniego Krawczyka. Lublin: Wydaw. Uniwersytetu Marii Curie-Skłodowskiej, s. 105-112.

Burbianka, Marta (1972). Wstęp do bibliografii (wyd. 3). Warszawa: Państwowe Wydaw. Naukowe.

Chłopkowska, Dorota (2009). Bibliografia w postaci bazy danych - nowa forma czy nowa jakość. W: Uniwersum piśmiennictwa wobec komunikacji elektronicznej. Pod red. Krzysztofa Migonia i Marty Skalskiej-Zlat. Wrocław: Wydaw. Uniwersytetu Wrocławskiego, s. 227-237.

Czapnik, Grzegorz; Gruszka, Zbigniew; Tadeusiewicz, Hanna, red. (2011). Podrecczny słownik bibliotekarza. Warszawa: Wydaw. Stowarzyszenia Bibliotekarzy Polskich.

Dembowska, Maria (1956). Bibliografia. W: Bibliotekarstwo naukowe: z uwzględnieniem dokumentacji naukowo-technicznej. Pod red. Adama Łysakowskiego. Warszawa: Państwowe Wydaw. Naukowe, s. 58-86.

Dembowska, Maria (1963). Rodzaje bibliografii. W: Metodyka bibliograficzna: poradnik dla autorów bibliografii specjalnych. Praca zbiorowa pod red. Heleny Hleb-Koszańskiej, Marii Dembowskiej i Henryka Sawoniaka. Warszawa: SBP, s. 26-48.

Derfert-Wolf, Lidia (2016). Bazy bibliograficzne a POL-index. Plusy i minusy, szanse i zagrożenia (na podstawie doświadczeń BazTech). Studia o Książce i Informacji, nr 35, s. 11-28.

Dramińska, Agnieszka; Kasprzyk-Machata, Joanna (2016). Narzędzia do rejestracji dorobku naukowego - od wykazu publikacji do uczelnianego repozytorium. W: Biblioteka na miarę: przestrzeń zasoby, ustugi. Pod red. Małgorzaty Świrad i Barbary Żmigrodzkiej. Wrocław: Wydaw. Uniwersytetu Ekonomicznego we Wrocławiu, s. 193-212.

Franke, Jerzy; Woźniak-Kasperek, Jadwiga (2016). Wygaszanie, marginalizowanie, redukowanie?: o kilku projektach katalogowo-bibliograficznych Biblioteki Narodowej. W: Bibliografi@: historia, teoria, praktyka. Praca zbiorowa pod red. Jerzego Franke i Jadwigi Woźniak-Kasperek. Warszawa: Wydaw. SBP, s. 179-201.

Giermaziak, Wojciech; Ubysz, Dorota; Głębocki, Jacek (2017). Polska Bibliografia Lekarska - perspektywy rozwoju. W: Bibliograficzne bazy danych: perspektywy i problemy rozwoju. III Konferencja Naukowa Konsorcjum BazTech. Kraków, 26-27 czerwca 2017 r. [online]. Red. Iwona Sójkowska, Lidia Derfert-Wolf. [dostęp: 21.05.2018]. Dostępny w WWW: http:// open.ebib.pl/ojs/index.php/Mat_konf/article/view/594/730, s. 1-9.

Gmiterek, Grzegorz (2016). Sieciowe sposoby społecznościowego zarządzania informacją o dokumentach. Zagadnienia Informacji Naukowej, vol. 54, nr 1, s. 108-133.

Jankowska, Elżbieta (2014). Bibliografia dorobku naukowego uczelni na przykładzie bazy tworzonej przez Bibliotekę Główną Zachodniopomorskiego Uniwersytetu Technologicznego w Szczecinie. Bibliotekarz Zachodniopomorski, R. 55, nr 1, s. 51-57.

Jaskowska, Małgorzata (2016). Funkcjonalność polskich bibliograficznych dziedzinowych systemów informacyjno-wyszukiwawczych. W: Bibliografi@: historia, teoria, praktyka. Praca zbior. pod red. Jerzego Franke i Jadwigi Woźniak-Kasperek. Warszawa: Wydaw. SBP, s. 223-237.

Jaworska, Karolina (2018). Nowa baza danych dla Polskiej Bibliografii Literackiej. W: Nauka o informacji w okresie zmian. Innowacyjne ustugi informacyjne. Praca zbior. pod red. Barbary Sosińskiej-Kalaty, Piotra Tafiłowskiego i Zuzanny Wiorogórskiej. Warszawa: Wydaw. SBP, s. 247-257. 
Kasprzak, Zofia; Polarczyk, Mariusz; Gmerek, Krzysztof (2017). Przyrodnicze i rolnicze zasoby nauki udostępniane cyfrowo w bazie AGRO. W: Bibliograficzne bazy danych: perspektywy i problemy rozwoju. III Konferencja Naukowa Konsorcjum BazTech. Kraków, 26-27 czerwca 2017 r. [online]. Red. Iwona Sójkowska, Lidia Derfert-Wolf. [dostęp: 21.05.2018]. Dostępny w WWW: http://open.ebib.pl/ojs/index.php/Mat_konf/article/view/583/723, s. 1-11.

Klenczon, Wanda (2016). Bibliografia narodowa: historyczna powinność czy niechciany obowiązek? W: Bibliografi@: historia, teoria, praktyka. Praca zbiorowa pod red. Jerzego Franke i Jadwigi Woźniak-Kasperek. Warszawa: Wydaw. SBP, s. 161-177.

Klenczon, Wanda (2009). Instytut Bibliograficzny - tradycja i nowe wyzwania. W: Bibliografia: teoria - praktyka - dydaktyka. Praca zbior. pod red. Jadwigi Woźniak-Kasperek i Mikołaja Ochmańskiego. Warszawa: Wydaw. SBP, s. 59-73.

Klimko, Renata (2015). Bibliometria w pracy bibliotekarza. Bibliotekarz Zachodniopomorski, R. 56, nr 1, s. 15-20.

Krynicka, Magdalena (2013). Bibliografia narodowa w świecie technologii sieci semantycznych. W: Bibliografi@: źródła, standardy, zasoby. Praca zbior. pod red. Jerzego Franke. Warszawa: Wydaw. SBP, s. 77-91.

Kycler, Maria (2015). Centrálny register záverečných a kvalifikačných prác - słowacka baza bibliografii zespołów osobowych i repozytorium prac dyplomowych. Nowa Biblioteka, nr 4, s. 57-74.

Mendykowa, Aleksandra (1981). Podstawy bibliografii. Warszawa: Państwowe Wydaw. Naukowe.

Milewska-Kozłowska, Joanna (2013-2014). Retrospektywna bibliografia narodowa Niemiec online (VD 16, VD 17, VD 18). Prezentacja baz. Z Badań nad Ksiązką i Księgozbiorami Historycznymi, t. 7-8, s. 253-272.

Narloch, Anna; Skrodzka, Justyna (2014). BazTech - baza indeksująca polskie czasopisma z zakresu nauk technicznych: wkład Biblioteki Głównej Zachodniopomorskiego Uniwersytetu Technologicznego w jej tworzenie. Bibliotekarz Zachodniopomorski, R. 55, nr 3, s. 5-13.

Nowak, Adam (2016). Problemy bibliografistyki średniowiecznej. W: Bibliografi@: historia, teoria, praktyka. Praca zbior. pod red. Jerzego Franke i Jadwigi Woźniak-Kasperek. Warszawa: Wydaw. SBP, s. 13-34.

Pacek, Jarosław (2008). Bibliografia 2.0. Zagadnienia Informacji Naukowej, z. 1, s. 35-44.

Pacek, Jarosław (2010). Bibliografia w zmieniajacym się środowisku informacyjnym. Warszawa: Wydaw. SBP.

Pacek, Jarosław (2007). Netografia universalis. Nowe oblicze bibliografii. W: Oblicza Internetu: architektura komunikacyjna sieci. Red. nauk. Marek Sokołowski. Elbląg: Wydaw. Państwowej Wyższej Szkoły Zawodowej, s. 241-251.

Partyka, Justyna; Urbańska, Aneta (2016). Tematyczne zestawienie literatury jako odpowiedź na zapotrzebowanie informacyjne w środowisku medycznym. W: Ekologia informacji a kultura informacyjna społeczeństwa. Pod red. Beaty Taraszkiewicz. Słupsk: Biblioteka Uczelniana Akademii Pomorskiej, Pedagogiczna Biblioteka Wojewódzka w Słupsku, Stowarzyszenie Bibliotekarzy Polskich. Zarząd Oddziału, s. 134-139.

Pasztaleniec-Jarzyńska, Joanna (2004). Biblioteka Narodowa i narodowa centrala bibliograficzna wobec Narodowego Uniwersalnego Katalogu Centralnego NUKAT. W: Piqta Ogólnokrajowa Narada Bibliografów: Warszawa 11-13 czerwca 2003: referaty $i$ dyskusja. [Oprac. dyskusji Danuta Bilikiewicz-Blanc i Anna Karłowicz]. Warszawa: Biblioteka Narodowa, s. 111-129. 
Sadowska, Jadwiga (2017). Bibliografia dziedzinowa dzisiaj - znaczenie i przyszłość. W: Bibliograficzne bazy danych: perspektywy i problemy rozwoju. III Konferencja Naukowa Konsorcjum BazTech. Kraków, 26-27 czerwca 2017 r. [online]. Red. Iwona Sójkowska, Lidia Derfert-Wolf. [dostęp: 21.05.2018]. Dostępny w WWW: http://open.ebib.pl/ojs/index. php/Mat_konf/article/view/582/722, s. 1-11.

Sadowska, Jadwiga (2016). Bibliografia zalecająca w Polsce. Przegląd Biblioteczny, R. 84, z. 2, s. 177-195.

Sadowska, Jadwiga (2010). Bibliografia i polityka w Polsce w latach 1946-1990. W: Niewygodne dla władzy. Ograniczenie wolności słowa na ziemiach polskich w XIX i XX wieku. Zbiór studiów pod red. Doroty Degen i Jacka Gzelli. Toruń: Wydaw. UMK, s. 255-273.

Sadowska, Jadwiga (2015). Dokąd zmierza bibliografia w „erze cyfrowej”? W: Teoretyczne zagadnienia bibliologii i informatologii: studia i szkice. Pod red. Elżbiety Gondek. Katowice: Wydaw. Uniwersytetu Śląskiego, s. 89-114.

Sawoniak, Henryk (1963). Ustalenie planu bibliografii i dobór materiałów. W: Metodyka bibliograficzna: poradnik dla autorów bibliografii specjalnych. Praca zbior. pod red. Heleny Hleb-Koszańskiej, Marii Dembowskiej i Henryka Sawoniaka. Warszawa: Stowarzyszenie Bibliotekarzy Polskich, s. 49-72.

Schabowicz, Olga (2011). Bibliografia zalecająca w Polsce - czy przestała być potrzebna? Bibliotekoznawstwo, t. 30, s. 101-118.

Socha, Irena (1984). Rodzaje opracowań bibliograficznych (form bibliografii). W: Rodzaje bibliografii. metodyka i technika ich opracowania. Pod red. Adama Jarosza i Zbigniewa Żmigrodzkiego. Warszawa: Centrum Informacji Naukowej, Technicznej i Ekonomicznej, s. 25-35.

Sowińska, Bożena (2013). Przypisy, powołania, bibliografia załacznikowa: poradnik. Bydgoszcz: Wyższa Szkoła Gospodarki w Bydgoszczy.

Stępień, Kamil (2013/2014). W stronę Bibliografii 2.0. Menedżer cytowań bibliograficznych Zotero. Folia Bibliologica, vol. 55/56, s. 183-192.

Szablewski, Maciej (2016). Nowa klasyfikacja Polskiej Bibliografii Bibliologicznej. Rocznik Biblioteki Narodowej, t. 47, s. 171-210.

Tafiłowski, Piotr (2016). Media społecznościowe jako źródło informacji bibliograficznej $\mathrm{w}$ naukach humanistycznych. Komunikat z badań. Zagadnienia Informacji Naukowej, vol. 54, nr 1, s. 55-66.

Wierzbicka-Próchniak, Dorota; Szewczyk-Kłos, Danuta (2017). Baza PEDAGOG - czy dziedzinowe bazy danych nadal są potrzebne użytkownikom informacji naukowej. W: Bibliograficzne bazy danych: perspektywy i problemy rozwoju. III Konferencja Naukowa Konsorcjum BazTech. Kraków, 26-27 czerwca 2017 r. [online]. Red. Iwona Sójkowska, Lidia Derfert-Wolf. [dostęp: 21.05.2018]. Dostępny w WWW: Dostępny w: http://open.ebib. pl/ojs/index.php/Mat_konf/article/view/593/729, s. 1-11.

Woźniak, Barbara; Ziółkowska, Małgorzata (2015). Od wykazu publikacji do narzędzia parametryzacji - dokumentacja dorobku naukowego pracowników Uniwersytetu Marii Curie-Skłodowskiej w zintegrowanym systemie zarządzania uczelnią. W: Biblioteka w czasie-czas w bibliotece. T. 2, Wspótczesność. Pod red. Stanisławy Wojnarowicz i Bogusława Kasperka. Lublin: Wydaw. Uniwersytetu Marii Curie-Skłodowskiej, s. 111-132.

Woźniak-Kasperek, Jadwiga (2015). Bibliografia a katalog biblioteczny: dyskusja o pojęciach i terminach. Przegląd Biblioteczny, R. 83, z. 4, s. 517-532.

Woźniak-Kasperek, Jadwiga (2010). Organizacja informacji w bibliografii. Tradycja i nowe możliwości. W: Szósta Ogólnokrajowa Narada Bibliografów. Warszawa, 23-24 października 2008. Oprac. red. Joanna Tarasiewicz. Warszawa: Biblioteka Narodowa, s. 115-130. 
Żmigrodzki, Zbigniew (2000). Typologia i klasyfikacja opracowań bibliograficznych. W: Bibliografia: metodyka i organizacja. Pod red. Zbigniewa Żmigrodzkiego. Warszawa: Wydaw. SBP, s. 35-45.

Artykuł w wersji poprawionej wptynąt do Redakcji 5 października 2018 r. 
AGNIESZKA GOŁDA

Institute of Library and Information Studies

Silesian University in Katowice

e-mail: agnieszka.golda@us.edu.pl

\section{TYPES OF BIBLIOGRAPHY IN DIGITAL ENVIRONMENT - SELECTED ISSUES}

KEYWORDS: Bibliography. Types of bibliography. „Full” bibliography. Preliminary bibliography. Topical compilation. Advisory bibliography. Reading list. Works cited/References. Bibliographical databases. Digital environment.

ABSTRACT: Thesis / Objective - The introduction of computer technology has resulted in changes to a number of elements of traditional bibliographies and methods of their construction. The article is focused on the presence of selected types of bibliography in the digital environment and their specific features and applications. Research methods - The author selected and analyzed bibliographies in the form of lists: "full" bibliographies, preliminary bibliographies, topical compilations, advisory bibliographies, reading lists and references. The source critique was used to present most important features of selected bibliography types and the comparative method was used to juxtapose the digital and traditional forms of bibliography. Results and conclusions - Various types of bibliography have found their place in the digital environment, with many of them altered to a significant extent. Full and preliminary bibliographies are run as bibliographical databases of continually evolving content and scope, adjusted to the users' needs and most often offering enhanced access to full texts with features specific for bibliography 2.0. Less changes can be noticed in topical compilations, advisory bibliographies and reading lists unless they are built for commercial purposes - their presence on the web facilitates access to specialized and profiled information. The construction of references has been made easier with computer tools such as bibliography generators and managers. 